
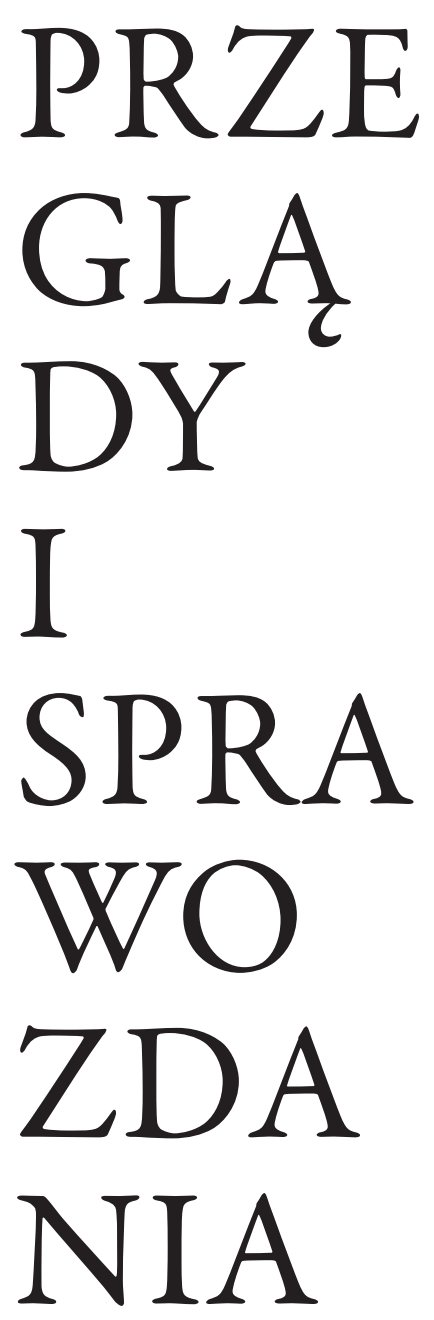

Sztuka Edycji 2/2019

ISSN 2084-7963 (print)

ISSN 2391-7903 (online)

s. $175-179$

\section{Beata Eukarska}

\section{Niezauważony dziennik duszy...}

Rzecz dotyczy publikacji wielowątkowej, a przy tym niezwykle szczerej i głębokiej. W 2005 roku nakładem poznańskiego wydawnictwa Pallotinum ukazał się Dziennik z życia autorstwa ks. Jana Sochonia ${ }^{1}$. Mimo upływu czasu, i mimo niezaprzeczalnej wartości publikacji, nie doczekała się ona, naszym zdaniem, właściwej oceny i odpowiedniej jej popularyzacji. O autorze, którego zarówno biografia, jak i dorobek naukowy oraz twórczy wymagałyby szerokiego, a zatem przekraczającego ramy tego studium, opracowania, informuje skromna nota zapisana na tylnej stronie okładki omawianej publikacji. Ksiądz profesor Jan Sochoń urodzony 17 sierpnia 1953 roku w Wasilkowie na Podlasiu jest teologiem, filozofem - tomistą, omawiającym zasadnicze kwestie filozofii Boga, filozofii religii, filozofii sztuki, publicystą, krytykiem literackim, eseistą, poetą, artystą-fotografikiem czy też wreszcie edytorem (m.in. dzieł Bolesława Leśmiana, Janusza S. Pasierba² ${ }^{2}$ Karola Wojtyły $^{3}$, pism ks. Jerzego Popiełuszki) oraz tłumaczem (teksty Étienne’a Gilsona).

Ponadto autora i jednocześnie bohatera wspomnianego dziennika w doskonały sposób tłumaczy on sam, wpisując w przedstawiony tekst informacje, tworzące swoisty autoportret:

Jestem warszawskim księdzem, nauczycielem uniwersyteckim. Uwielbiam sztukę wysoką, fotografowanie, magię studia radiowego oraz ballady z gatunku smooth jazz. Swą wrażliwość religijną związałem z twórczością artystyczną. 
Dzień bez postawienia kilku znaków graficznych uważam nie tyle za stracony, ile raczej mniej przemedytowany $[\ldots]^{4}$.

Decydując się na publikację swojego Dziennika z życia, Jan Sochoń nawiązuje z całą pewnością, i to zapewne w sposób świadomy i zamierzony, do wielowiekowej tradycji pisania tzw. dzienników duszy czy też dzienników duchowych. Tradycji owocującej niezwykłymi pomnikami życia, myśli i wiary zarówno w odległej historii, jak i współcześ$n^{2} e^{5}$. Dziennik Sochonia staje się ponadto w swej strukturze jawnej, jak i obecnej pośrednio, aluzyjnie, interesującym literackim i kulturowym centonem, wyborem myśli i sądów wielu przywołanych autorów.

Wydawca szczęśliwie nie złamał owej wpisanej w autorski tekst jedynej w swoim rodzaju korelacji między słowem własnym autora a każdym przypadkiem i sposobem zaistnienia wypowiedzi innych postaci. Dzięki temu piękno naturalnego toku rozmowy z czytelnikiem nie zostało zaprzepaszczone przez użycie sztucznego wobec zamysłu autorskiego uporządkowania owej specyficznej wewnętrznej harmonii zapisków, owej różnorodności, nieoczekiwanego następstwa wyznań duchowych, modlitw, przemyśleń o chwiejnej kondycji współczesnego świata, ludziach i tworzonej przez nich kulturze. Dzięki temu Dziennik z życia pióra ks. Jana Sochonia przechodzi niekiedy w formę zbliżoną do raptularza, w którym za pomocą żywiołu wspomnień przeziera zarówno akademicki wykład autora, jak i poezja (własna i cudza), a także - spowalniając nieco tok dłużyzny autorskiej wypowiedzi, trochę na kształt klasycznej retardacji - słowa licznego grona wspominanych osób oraz listy pisane przez przyjaciół i znajomych.

W Dzienniku ks. Sochonia mamy ponadto do czynienia z zapisaną syntezą sztuk, objawiającą się w powiązaniu tekstów poetyckich (niekiedy szerzej: literackich) własnych i cudzych z komentarzami na temat malarstwa i muzyki (od chorału gregoriańskiego, przez muzykę jazzową, do muzyki rockowej), sztuki filmowej (Agnieszka Holland - skojarzona z urodą ogrodu, będącego własnością rodziny ${ }^{6}$, ocena głośnego niegdyś filmu w reżyserii Mela Gibsona o tytule Pasja w kontekście kościelnej tradycji sztuki pasyjnej’).

$\mathrm{Z}$ treściami o charakterze społeczno-politycznym omawianego Dziennika identyfikować się mogą ci wszyscy, których historia życia rozciąga się między epoką totalitaryzmu komunistycznego przez stan pokojowej transformacji do przejścia w nową rzeczywistość społeczno-polityczną. W perspektywie dziejów Kościoła, zarówno powszechnego, jak i rodzimego, oznacza to czas od ożywczego fermentu Soboru Watykańskiego II do dyskusji znamiennych dla najbardziej aktualnych problemów wspólnoty katolickiej.

W rzeczywistości pokoleniowej zostały zanurzone: wolny głos społeczności polskiej na Zachodzie, tj. Radio Wolna Europa (zakłócanych audycji emigracyjnej rozgłośni z uwaga nasłuchuje ojciec autora - Franciszek Sochoń), późne echa posoborowe i nie w pełni wykorzystana wiosna Kościoła (w kontekście nowej formacji i nowych form duszpasterstwa młodzieży) ${ }^{8}$, żywy ruch ekumeniczny (podpisanie Deklaracji o Usprawiedliwieniu) ${ }^{9}$, trudne, a nawet tragiczne wydarzenia późnej i schyłkowej fazy dawnego systemu ustrojowego (zabójstwo kapelana ruchu wolnościowego i patriotycznego ks. Jerzego Popiełuszki) ${ }^{10}$, powszechna nadzieja zbliżającej się wolności i odnowy powiązanej z Janem Pawłem II, papieskim pielgrzymowaniem, przemówieniami skierowanymi do Polaków, do młodzieży, reakcjami na teksty oficjalnych dokumentów papieskich: Encyklik (Evangelium vitae, Fides et ratio).

Dziennik z życia to także świadectwo zmagania się ze słabością ludzkiej natury, z samym sobą, przede wszystkim w kontekście narzuconych wymogami stanu kapłańskiego ograniczeń osobistej wolności (osamotnienia, celibatu), świadectwo potrzeby miłości i bliskości drugiego człowieka, świadectwo wreszcie niezwykłej wrażliwości wobec bieżących dyskusji, toczonych w perspektywie szeroko rozumianej wspólnoty Kościoła, państwa, świata.

Dziennik z życia to wreszcie konsekwentnie budowana antropologia filozoficzna, filozofia człowieka, w której, obok Augustyńskiej wizji bytu ludzkiego, do głosu dochodzą renesansowa afirmacja cielesności (a właściwie nagości jednocześnie ukrytej i odsłoniętej w wizerunku postaci ze słynnych fresków Kaplicy Sykstyńskiej), barokowa semantyka (w kontekście tajemnicy wcielenia Syna Bożego, a właściwie, jak w sposób symboliczny ujął to autor, „przyjętej przez Chrystusa lepianki doczesnego ciała ludzkiego”) ${ }^{11}$ i ostatecznie współczesne niepokoje ludzkości (m.in w odniesieniu do filozoficznego traktatu Sørena Kierkegaarda) ${ }^{12}$, dawne i nowe koncepcje czasu i przestrzeni.

Publikacja ks. Sochonia stanowi też obraz jego literackich zainteresowań, w formule wypowiedzi wkraczających niejednokrotnie w sferę krytyki literackiej. Poznajemy refleksje z osobistych lektur, w tym lektur filozoficznych, ich indywidualną, głęboko przemyślaną albo, jak podkreśla autor, przemedytowaną wykładnię treści, pojęć, znaczeń. W obszarze lekturowych przywołań pojawią się kolejno:

- filozofowie, teologowie, pisarze kościelni i religijni. Wśród nich urodzona we Wrocławiu, zamęczona 
w oświęcimskim obozie, niemiecka filozofka żydowskiego pochodzenia, karmelitanka bosa, święta Kościoła katolickiego, patronka Europy - Edyta Stein ${ }^{13}$;

- kilkukrotnie wspomniany św. Augustyn, np. w ciekawie brzmiącym, metonimicznym stwierdzeniu: „Czytam św. Augustyna, w pięknym tłumaczeniu Zygmunta Kubiaka. Słyszę zdania, które otworzyły drogę Szekspirowi, Dantemu i naszej przedziwnej epoce" ${ }^{14}$;

- jeden z najwybitniejszych współczesnych teologów katolickich, Walter Kasper, i jego głośna książka Bóg Jezusa Chrystusa, wydana w polskim tłumaczeniu w Warszawie w 1996 roku;

- Emmanuel Levinas w aluzyjnym przywołaniu traktatu o Bogu objawiającym się w ,innym człowieku” ${ }^{15}$;

- hinduski jezuita, Anthony de Mello, którego książka Przebudzenie ${ }^{16}$ była obowiązkową lekturą dla wielu osób związanych z licznymi wspólnotami duszpasterstwa młodzieżowego, w tym z kręgiem pedagogii ks. Franciszka Blachnickiego i ruchu o nazwie „Światło i Życie”, określanego popularnie mianem „Oazy”;

- Ryszard Przybylski w kontekście publikacji o intrygującym tytule Pustelnicy i demony w odniesieniu do tradycji duchowości tzw. Ojców Pustyni ${ }^{17}$.

Nawet wspomnienia osób bliskich, przyjaciół stają się niekiedy pretekstem do swobodnego, czasem tylko aluzyjnego przywołania innych tekstów literackich, jak w przypadku rozważań dotyczących istoty przyjaźni: „Mieć przyjaciela to wielki dar. Często nie trzeba wiele mówić. Uśmiech, świadomość, że mogę opowiedzieć całego siebie, i pozostanie to wspólnym językiem obecności, przynoszą wytchnienie, radość"18, w których uważny czytelnik rozpozna słowa traktatu francuskiego filozofa-humanisty, Antoine'a de Saint-Exupéry'ego, wypowiedziane przez lisa podlegającego procesowi oswojenia przez Małego Księcia ${ }^{19}$.

Dziennik księdza-poety kryje poza tym portrety ludzi kultury i nauki. W zwielokrotnionym mechanizmie wspomnień zostaną ukazani inni księża-poeci: ks. Jan Twardowski, ks. Janusz Pasierb, reprezentanci współczesnej polskiej literatury i kultury: Czesław Miłosz ${ }^{20}$, Zbigniew Herbert ${ }^{21}$, Adam Zagajewskii ${ }^{22}$, Wiktor Woroszylski, Marek Skwarnicki, Józef Czapski²3, Wisława Szymborska, Jerzy Grzegorzewski i wielu innych. Słowa uznania zostaną skojarzone z działalnością publicystyczną ks. Adama Bonieckiego. Dziennik Jana Sochonia stanie się także miejscem publikacji stosunkowo obszernej i szczegółowej relacji z uroczystości zorganizowanej dla uczczenia pięćdziesięciolecia pracy naukowo-dydaktycznej ks. prof. Mieczysława Alberta Krąpca (zwłaszcza streszczenie nauczania i zarazem jubileuszowego wykładu $)^{24}$.

$\mathrm{Na}$ tym tle do szczególnej rangi urastają zapisy tworzące wyraźny wymiar autotematyczny Dziennika. Uwagi w rodzaju:

Uznaję siebie za poetę 25 .

Pisanie wierszy to cudowny $\mathrm{dar}^{26}$.

Należę do osób szczęśliwych. Wiersze, które rodzą się we mnie, przynoszą chwile wytchnienia, uciszenia serca jako znaki wewnętrznego pokoju i zgody na samego siebie ${ }^{27}$.

W wierszu rozmawiam, zapraszam do rozmowy i czekam na życzliwe gesty porozumienia... ${ }^{28}$

- rozproszone w całym tekście, pozwalają lepiej poznać i zrozumieć znaczenie i wartość aktu twórczego poety.

Istotę twórczości i osobistej wrażliwości zawierają także komentarze na temat dosłownej, ale subtelnej zmysłowości, która w niezrozumiały dla diarysty sposób gorszy, a nawet oburza niektórych spośród pilnych czytelników jego poezji. Ksiądz Sochoń słusznie w tym miejscu tłumaczy tradycję słowa biblijnego, która w obrazowaniu cielesnej bliskości zakochanych (narzeczonych, małżonków, tu także duchowość nupcjalna), w obrazie pożądania i erotyki zamyka przekaz miłości Boga do człowieka, człowieka do Boga, Kościoła do wiernych i wiernych do Kościoła ${ }^{29}$.

Realizm reportażowego obrazowania, obecny już we wcześniej wspomnianej relacji z akademickich uroczystości ku czci prof. Mieczysława Krąpca, raz jeszcze dochodzi do głosu w uwagach dotyczących obserwacji wydarzeń bieżących, zmian dokonujących się tuż obok, w najbliższym środowisku autora. Refleksje godne filozofa budzą bowiem obrazy rozpoczynającej się budowy warszawskiego metra, procedur bezpieczeństwa obserwowanych podczas odlotu z Warszawy do Gdańska, tłumu ludzi w różnym wieku zdążających na koncert Michaela Jacksona.

Osobną, bardzo rozbudowaną i po wielekroć powracającą częścią Dziennika stają się rozważania na temat historii i współczesności życia duchowego, ważnych aspektów teologii, wykładni znaczeń zawartych w liturgii, tradycji i zróżnicowaniu formalnym i treściowym praktyk modlitewnych ${ }^{30}$. Odzywają się one po części na prawach wykładu akademickiego, po części popularyzującego omówienia, zawsze natomiast w łączności z osobistym świadectwem intymnych, 
szczerych przemyśleń, doświadczeniem własnego wnętrza. Autor ponadto przekonująco i dostatecznie sugestywnie zanurza czytelnika w pięknie i mistycyzmie rytuału roku liturgicznego (refleksje na temat świąt Wszystkich Świętych, Bożego Narodzenia, czasu pasyjnego i wielkanocnego), a także konieczności zbliżenia podzielonego chrześcijaństwa w kontekście ważnych inicjatyw ekumenicznych.

Ksiądz Jan Sochoń dokumentuje wybrane aspekty posługi papieskiej papieża Jana Pawła II, pamiętne pielgrzymki do ojczyzny, publikowane papieskie dokumenty, powszechne nauczanie i wreszcie smutne chwile schyłku życia. Poza tym włącza się do dyskusji o przyszłości i koniecznych zmianach w Kościele, postulując, jak większość znanych autorytetów naszych czasów, konieczność pogłębienia instytucjonalnej odnowy, kontynuacji zasad nowej ewangelizacji, pełniejszego włączenia aktywności wiernych.

Nieskrywany niepokój diarysty budzą natomiast wyraźne znamiona kryzysu wartości, kryzysu duchowego przełomu tysiącleci. Pisze on o rzeczywistości, która wymusza przyjęcie postawy nieufności, a nawet podejrzliwości, o zagubieniu instytucji autorytetu, wzorców moralnych godnych twórczego naśladowania, o zachłyśnięciu się pseudowartościami tworzącymi ostatecznie tę rzeczywistość, którą za wspomnianym Janem Pawłem II zwykło określać się „cywilizacją śmierci”. Sprzeciw duchownego budzą ponadto obserwowane objawy współczesnej komercjalizacji życia religijnego, jego okazjonalna odpustowośćc ${ }^{31}$, a w dziedzinie socjologii kultury źle pojęta i instrumentalnie wykorzystywana krytyka feministyczna ${ }^{32}$.

W kontekście Kościoła w Polsce w zapisach publikacji ks. Jana Sochonia pojawia się również prawdziwy dyskurs tożsamościowy rozpięty między polską tradycją religijną, tradycyjnie rozbudowaną maryjnością, ideologią antemurale christianitatis, romantycznym, i nie tylko, mesjanizmem ${ }^{33}$ a spuścizną rodzimej kultury religijnej i rozwijającym się za sprawą postaci św. Faustyny Kowalskiej i jej duchowego kierownika ks. Michała Sopoćki ${ }^{34}$ kultem Bożego Miłosierdzia.

Całość rozważań z zakresu umysłu i ducha zamyka część, którą można opatrzyć symbolicznym mianem opisów przestrzeni podróży, a mianowicie: piękna pomników natury rozsianych na rozległych przestrzeniach Stanów Zjednoczonych, egzotyki Martyniki, krajobrazów średniowiecznych miasteczek Umbrii i rozległych pól Toskanii, cudów architektury Paryża, zwłaszcza zachwytu wobec geometryczno-symbolicznej doskonałości średniowiecznej katedry Notre Dame ${ }^{35}$.

Wreszcie, wzbogacenie dziennika o materiał ilustratorski, w postaci zdjęć pochodzących zapewne z własnej kolekcji autora, stanowi nie tylko wizualne uzupełnienie pisarskiego wywodu, ale i realne ucieleśnienie osób opisywanym słowem pamiętnikarskiej narracji.

Puentując tę wypowiedź, pozostaje mieć nadzieję, że kilka skreślonych w tym miejscu uwag na temat wartości Dziennika z życia autorstwa ks. Jana Sochonia przekona do poznania owego nieco zapomnianego tekstu jako fascynującej lektury o Polsce, świecie, kondycji duchowej i kulturowej człowieka przełomu stuleci i tysiącleci. I że lektura ta przyniesie lepsze porozumienie co do rzeczywistej roli i autentycznej wartości wspólnoty Kościoła, ujawniających się w doświadczeniu konkretnego człowieka.

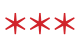

ks. J. Sochoń, Dziennik z życia, Wydawnictwo Pallottinum, Poznań 2005

'Swoistym przygotowaniem do pełnego wydania Dziennika wydaje się nieco wcześ niejsza (ukazała się w Warszawie w 2004 roku) publikacja autorstwa ks. Jana Sochonia, tytułem nawiazująca do wczesnośredniowiecznego myśliciela - Boecjusza z Dacji;

ks. J. Sochoń, O pocieszeniu, jakie daje literatura. Szkice i uwagi krytyczne, Warszawa 2004. Fragmenty Dziennika zostały zawarte na s. 255-411.

${ }^{2}$ Zob. odpowiednie rozdziały publikacji O pocieszeniu, jakie daje literatura (s. 87-132) oraz Szczerość i maska. (O wierszach księdza Janusza Stanisława Pasierba), w: ks. J. Sochoń, U drzwi Godot. Szkice o poezji, filozofii i teologii, Warszawa 1995, s. 60-68.

${ }^{3}$ Nie jestem samotny, bo drżę. O twórczości Karola Wojtyły, w: ks. J. Sochoń, O pocieszeniu, jakie daje literatura, s. 6-80.

${ }^{4}$ Idem, Dziennik z życia, Poznań 2005, s. 6.

${ }^{5}$ Dzienniki tego rodzaju były nie tylko zapisanym świadectwem życia duchowego i intelektualnego, ale czesto łączyły się z doświadczeniem mistycznym, potwierdzonym objawieniami. Z dawnych przekazów tego rodzaju można wskazać: św. Katarzyna ze Sieny, Dialog o Bożej Opatrzności, czyli Księga Boskiej Nauki, łłum. L. Staff, Poznań 1987. Wśród nowszych dzieł tego rodzaju w pamięci czytelniczej zapisały się: Jana XXIII, Dziennik duszy, w tłum. J. Ledóchowskiej, Warszawa 2014, oraz niezwykle dziś znaczący w perspektywie duchowości, powiązanej z kultem Bożego Miłosierdzia: Błogosławiona s. M. Faustyna Kowalska, Dzienniczek. Miłosierdzie Boże w duszy mojej, Warszawa 1999. Jedną z najnowszych postaci pośród autorów dzienników duchowych jest natomiast Alicja Lenczewska. Spisane przez Lenczewską rozważania, wizje duchowe, znalazły się w: Świadectwo. Dziennik duchowy, Po znań 2018.

'Ksiądz Sochoń zapisał słowa następujące: „Mieliśmy w Sochoniach (to wioseczka leżąca blisko Wasilkowa) wielki ogród, podobny do tego, który sfilmowała onegdaj Agnieszka Holland"; ks. Jan Sochoń, Dziennik, s. 7.

7 Ibidem, s. 341.

${ }^{8}$ Ważne wspomnienia przywołane przez autora w kontekście osoby wychowawcy, mentora, przyjaciela - ks. Piotra Bożyka. W Dzienniku m.in. następujace stwierdzenia: „Jego zaangażowanie, jak wspomniałem, przypadło na lata komunistycznego ucisku i prób dobijania się do polskiej wersji demokratycznej niepodległości. Zakochawszy się w ideach wychowawczych św. Jana Bosko, starał się wprowadzać je w życie ministrantów, co musiało napotkać opór urzędników Służby Bezpieczeństwa". Podobnie w innym miejscu publikacji: „I chociaż tego rodzaju duszpasterstwo wywoływało kontrowersje, to przecież właśnie ono stanowiło swego rodzaju prekursorski zaczyn rozwijanych później ruchów oazowych, studenckich, czy działalności prowadzonej obecnie przez 0. Jana Górę". Warto skonfrontować opisane przez autora doświadczenia z najnowszymi refleksjami naukowymi i pedagogicznymi na ten temat zebranymi w publikacji: Duszpasterstwo młodzieży w Polsce wobec współczesnych przemian, Warszawa 2018. 
${ }^{9}$ Opublikowana w: Deklaracja o usprawiedliwieniu. Historia powstania, tekst deklaracii, opinie, komentarze, Bielsko-Biała 2000.

${ }^{0}$ Między innymi odniesienia do kolejnych rocznic tragicznej śmierci, do wypuszczenia na wolność zabójcy kapłana, Grzegorza Piotrowskiego; ks. J. Sochoń, Dziennik, s. 123 i 126-127.

Narzucające się uwadze czytelnika ukryte sensy lektur, przeniesione w wymiar własnego języka. O specyfice nazewnictwa ludzkiego ciała w stylistyce barokowej powstało przecież sporo opracowań, spośród których można wyróżnić dla przykładu: A. Wilkoń, Dzieje języka artystycznego w Polsce. Język i style literatury barokowej, Kraków 2002. Zob. też: O. Clément, Ciało śmiertelne i chwalebne. Wprowadzenie do teopoetyki ciała, tum. M. Zurowska, Warszawa 1999; H. Dziechcińska, Wizja ciała człowieka w literaturze polskiego baroku, w: Między barokiem a Oświeceniem. Apogeum sarmatyzmu. Kultura polska drugiej połowy XVII wieku, pod red. K. Stasiewicz i S. Achremczyka, Olsztyn 1997, s. 78-85.

${ }^{2}$ S. Kierkegaard, Bojaźń i drżenie, z oryginału duńskiego przet. i wstępem opatrzył J. Iwaszkiewicz, Poznań 1995

${ }^{3}$ ks. J. Sochoń, Dziennik, s. 21.

${ }^{4}$ Ibidem, s. 17.

E. Levinas, O Bogu, który nawiedza myśl, tłum. M. Kowalska, Kraków 1994.

${ }^{6}$ Zob. następne wydania: Poznań 2015, Kraków 2018

${ }^{7}$ Aluzyinie przywołana tradycja ascetyczna, opisana tradycją literacką takich tytułów, jak: Pierwsza Księga Starców. Gerontikon, Kraków 1992, Druga Księga Starców. Verba Seniorum, ttum. M. Kozera, wstęp M. Starowieyski i L. Regnault, oprac. M. Starowieyski, Kraków 1996.

${ }^{18}$ ks. J. Sochoń, Dziennik, s. 55; powtórnie na s. 161.

${ }^{9}$ Zob. fragment zawarty w: A. de Saint-Exupéry, Mały Książe, ttum. J. Szweykowski, Warszawa 1991, s. 58-65.

${ }^{20}$ Zob. Pochwała rzeczy. (O poezii Czestawa Miłosza) oraz Miasto Mitosza. (Topos miasta w poezij Miłosza), obydwa rozdziały w: ks. J. Sochoń, U drzwi Godot, s. 68-77 i 78-89.

'Zob. też szkic o poezji Zbigniewa Herberta: Szare numinozum. (0 poezji Zbigniewa Herberta) oraz Album Herberta. (Nowy zbiór wierszy), w: ibidem, s. 98-104 i 105-109.

${ }^{2}$ ks. J. Sochoń, Poszukiwanie formy. (O twórczości Adama Zagajewskiego), w: ibidem, s. $116-121$.

${ }^{3}$ Idem, Ścieżki sztuki i cierpienia. (O Józefie Czapskim), w: ibidem, s. 179-183.

${ }^{24}$ Idem, Dziennik, s. 77-80.

${ }^{25}$ Ibidem, s. 8.

${ }^{26} \mathrm{Ibidem}$.

${ }^{27}$ Ibidem, s. 9.

${ }^{28} \mathrm{lbidem}$.

${ }^{29}$ Słowa ks. Sochonia: „A więc mam za swoje, za wszystkie ciała, nagie stopy, krople potu, usta delikatnie otwarte, sukienkę przytuloną do ciała. Być może obrażam uczucia, wrażliwość religijną, burzę wewnętrzny pokój. Jednak w Pieśni nad pieśniami, w przepięknym tłumaczeniu Jakuba Wujka SI, już w pierwszych wersach czytam:

Niech mie pocałuje

pocałunkiem ust swoich,

bo lepsze są piersi twe nad wino".

Ibidem, s. 37. Zob. też w tym kontekście: A. Blusiewicz, Ogień miłości. Z przemyśleń nad recepcją "Pieśni nad pieśniami” w polskiej poezji barokowej, „Przegląd Powszechny” 1985, z. 7-8.

${ }^{30}$ Autor wielokrotnie wspomina np. o znaczeniu i tradycji modlitwy różańcowej; ks. J. Sochoń, Dziennik, s. 49 i 248. Zob. też m.in.: Z. J. Kijas, Różaniec, czyli ponad przymusem teraźniejszości, Kraków 2013

${ }^{11}$ Ksiądz Sochoń odnosi te uwagi m.in. do tradycji odpustu w Świętej Wodzie: „Obecnie w przestrzeń Ś wietejej Wody wkroczyła nowoczesna komercja, odstraszająca swą brzydotą i tzw. duszpasterstwem pielgrzymkowym, głośnym, rozśpiewanym, akcyjnym"; ks. J. Sochoń, Dziennik, s. 114. Zob. też podobne uwagi w pracy Krzysztofa Koehlera: K. Koehler, Zejście z Jasnej Góry? Kilka uwag o długim trwaniu sarmackiej religijności, „Teksty Drugie” 2015, nr 1, s. 404-417.

32 Zob. pierwsze dyskusje na temat ideologii gender: ks. J. Sochoń, Dziennik, s. 187-188, oraz uwagi autora o kulturze i filozofii postmodernistycznej w: idem, Spór o rozumienie świata. Monizujące ujęcia rzeczywistości w filozofii europejskiej. Studium historyczno-hermeneutyczne. Warszawa 1998, s. 446-459.

${ }^{3}$ Zob. w tym kontekście zbiorową publikację o charakterze naukowym: Mesjańskie imaginaria Europy (i okolic). Studia komparatystyczne, pod red. A. Janek, A. Regiewicza i A. Żywiołka, Częstochowa 2015

${ }^{34}$ Jeden z traktatów Sopoćki: Poznajmy Boga w Jego miłosierdziu. Rozważania o Mitosierdziu Bożym na tle litanii, Poznań 1949

35 Jakże podobne są zachwyty autora wobec symboliki paryskiej świątyni do uwag o geometryzacji i sakralnej symbolice wnętrza średniowiecznych katedr opisanych w: J. Hani, Symbolika świątyni chrześcijańskiej, tłum. A. Q. Lavique, Kraków 1998.
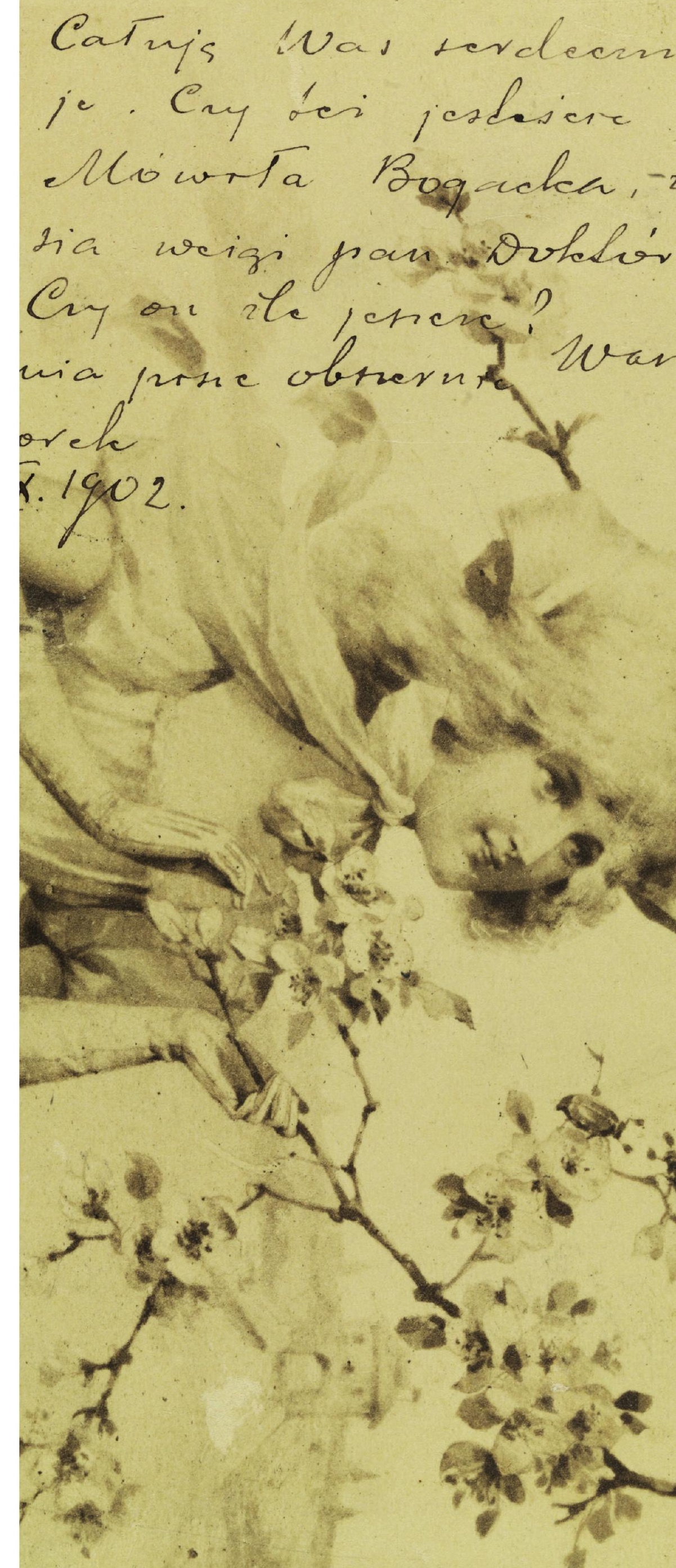